\title{
Language, Ethnicity, and Separatism: Survey Results from Two Post-Soviet Regions
}

\author{
Kyle L. Marquardt \\ School of Politics and Governance and International Center for the Study of Institutions and Development, HSE University, \\ Moscow, Russia \\ Corresponding author. Email: kmarquardt@hse.ru
}

(Received 7 May 2020; revised 9 March 2021; accepted 8 August 2021; first published online 22 December 2021)

\begin{abstract}
Scholars often use language to proxy ethnic identity in studies of conflict and separatism. This conflation of language and ethnicity is misleading: language can cut across ethnic divides and itself has a strong link to identity and social mobility. Language can therefore influence political preferences independently of ethnicity. Results from an original survey of two post-Soviet regions support these claims. Statistical analyses demonstrate that individuals fluent in a peripheral lingua franca are more likely to support separatism than those who are not, while individuals fluent in the language of the central state are less likely to support separatist outcomes. Moreover, linguistic fluency shows a stronger relationship with support for separatism than ethnic identification. These results provide strong evidence that scholars should disaggregate language and ethnic identity in their analyses: language can be more salient for political preferences than ethnicity, and the most salient languages may not even be ethnic.
\end{abstract}

Keywords: separatism; language politics; post-Soviet politics; survey experiments; Bayesian methods

Prominent research argues that differences in ethnic group characteristics increase the likelihood of civil conflict and separatism (Bormann, Cederman, and Vogt 2017; Caselli and Coleman 2013; Esteban, Mayoral, and Ray 2012; Vogt 2018). Language is a key ethnic attribute in many of these accounts: ethnic groups with distinct languages are more likely to engage in conflict with other groups or a central state, as are groups that have many members who speak their "native" language. However, there is increasing evidence that this limited conceptualization of languagethat it mainly serves to intensify the effect of ethnicity-belies its independent importance to identity and political outcomes, including national identity and separatism (Marquardt 2018; Onuch and Hale 2018; Pérez and Tavits 2019; Pop-Eleches and Robertson 2018; Rodon and Guinjoan 2018; Siroky et al. 2021).

There are theoretical reasons to believe that language, in and of itself, may be important for separatism. Traditional ethnic theories of separatism hold that the individuals most likely to engage in conflict with the central state are those who: (1) share an identity; (2) perceive blocked social mobility; and (3) have less access to state institutions (Cederman, Gleditsch, and Buhaug 2013; Cederman, Wimmer, and Min 2010; Gellner 1983; Gurr 1993). Language fulfils all three of these criteria: it is fundamental to the development of a common identity (Anderson 2006), and speaking the language of a central state can be essential for social mobility and access to state institutions (Laitin and Ramachandran 2016; Marquardt 2018). This link between language and theories of separatism yields several clear empirical expectations. First, individuals who

\footnotetext{
(c) The Author(s), 2021. Published by Cambridge University Press. This is an Open Access article, distributed under the terms of the Creative Commons Attribution-NonCommercial-ShareAlike licence (http://creativecommons.org/licenses/by-nc-sa/4.0), which permits non-commercial re-use, distribution, and reproduction in any medium, provided the same Creative Commons licence is used to distribute the re-used or adapted article and the original article is properly cited. The written permission of Cambridge University Press must be obtained prior to any commercial use.
} 
only speak the language of a peripheral region should be those most likely to support separatism: they share a peripheral linguistic identity, and due to their lack of fluency in a central language, they potentially face blocked mobility and difficulty accessing resources in the central state. Second, individuals who speak the language of the central state should be less supportive of separatism since they: (1) share an identity with the center; and (2) face neither linguistic blocked mobility nor hindrances in accessing state institutions in the center.

This logic stands in contrast to the traditional approach to language in studies of ethnic separatism: language has a direct link to separatist sentiment, independent of its relationship to ethnic identity. An individual's linguistic preferences over separatist outcomes may, in fact, run counter to their ethnic preferences: a member of a peripheral ethnic group who only speaks the language of the central state may oppose separatism given the linguistic advantages integration with the central state provides them. Equally importantly, the language(s) most relevant for separatism may not even be linked to a particular ethnic group: a peripheral lingua franca may be more relevant for day-to-day life than ethnic languages and thus more salient for separatism.

In this article, I investigate the relationship between language, ethnicity, and support for separatism using original survey data from two Eastern European regions, both de jure territorial units of the post-Soviet state of Moldova: the Pridnestrovian Moldavian Republic (Pridnestrovie, also known as Transnistria) and Gagauz Yeri (Gagauzia). The Slavic Russian language is both a lingua franca and the language most closely linked to social mobility in both regions. The language of the central state, Moldovan (a Romance language), is of limited utility in both Pridnestrovie and Gagauzia but is increasingly essential in Moldova proper. These two regions thus provide a context in which language is likely to be salient for separatism: speakers of Russian have greater opportunities in these regions than they do in Moldova proper and have a common linguistic identity distinct from that of the population of the central state.

Pridnestrovie and Gagauzia also provide analytic leverage for disaggregating the influence of language from ethnic identity. Specifically, a non-Moldovan ethnic group represents the plurality or majority population in both regions: Russians constitute at least 30 per cent of the population of Pridnestrovie, while the Turkic Gagauz constitute over 80 per cent of Gagauzia's population. If a sense of ethnic kinship is most relevant for separatist sentiment, members of these peripheral ethnic groups should be most supportive of separatism. If language intensifies ethnic sentiment, then ethnic Russians who speak only Russian and ethnic Gagauz who speak Gagauz-not Russian-should most support separatist outcomes.

Analyses of observational data indicate that language has a stronger relationship with support for separatism than does ethnic identification: in both regions, speakers of the main peripheral language (Russian) are the most supportive of separatist outcomes, regardless of their ethnic affiliation. Moreover, monolingual speakers of a peripheral language linked to ethnic identity (Gagauz in Gagauzia) are less supportive of separatism than speakers of the main peripheral language (Russian).

While these results are congruent with claims about the importance of language to separatism, causal identification remains a concern. In addition to a case selection that facilitates disaggregating language from ethnic identity - the most likely confounding variable-I engage with identification in two ways. First, I analyze a survey experiment that primed respondents to consider their linguistic abilities prior to reporting support for separatism. Results from the experiment indicate that linguistic abilities - not identification with an ethnic group-account for the relationship between language and support for separatism. Second, the Online Appendices contain detailed observational analyses illustrating that factors related to identity do not directly determine linguistic proficiency.

If we are living in an "age of secession" (Griffiths 2016), then understanding why individuals support separatist outcomes is of vital importance. This article contributes to this literature in two main ways. First, peripheral lingua francas have played a role in separatist mobilization around the world, with cases ranging from Russian across the former Soviet Union, to English in the 
Ambazonia region of Cameroon. This article provides insight into this phenomenon by illustrating how a peripheral lingua franca (Russian) can unite individuals of different ethnic backgrounds to support separatist ends. Second, while peripheral linguistic and ethnic identities are more difficult to disentangle in many important cases of separatism-such as Catalan in Catalonia and Tibetan in Tibet-this article demonstrates that language is conceptually and empirically distinct from ethnic identity. Moreover, the analyses in the article show that language can be more salient for separatism than ethnic identity. Together, these results indicate that conflating language and ethnicity risks fundamentally misidentifying the roots of separatism, even in cases where these concepts overlap.

\section{Ethnicity and Sparatism}

Separatism is a matter of territory: a peripheral population demands greater autonomy or independence for their region. Scholars generally assess a region's identity-based propensity for separatism by focusing on the relative opportunities that separatism offers members of peripheral ethnic groups. ${ }^{1}$ Primary explanations are: (1) blocked social mobility; and (2) differential access to resources. Gellner (1983) holds that the ethnic groups most likely to engage in separatism are those that face permanently blocked social mobility: members of these groups believe they will never have equal opportunities as long as they are part of a state dominated by another group. Scholarship associated with the Ethnic Power Relations project argues that co-ethnicity with a state's leadership determines access to state resources; excluded groups have no such access and are thus most likely to engage in conflict (Cederman, Wimmer, and Min 2010).

The explanation of why ethnicity - as opposed to other social identities-serves as the mobilizing nexus for separatism varies. However, a common thread is that ethnic identity is uniquely powerful in imbuing a sense of common experiences and purpose among its members. For example, Hale (2008) proposes that ethnic groups are particularly likely to solve the commitment problems inherent in separatism; members of these groups believe that co-ethnics share their preferences due to similarities in tangible characteristics and more intangible shared culture. As a result, they can reasonably believe that the leadership of a state in which members of their group dominate will act in accordance with their interests.

\section{Ethnic Attributes and Separatism}

Another body of literature argues that a focus on ethnicity writ large belies substantial intra- and interethnic variation in ethnic identity salience. This argument has important implications for understanding purportedly ethnic separatism. For example, Chandra (2006; Chandra 2012, 1178) notes that many theories of ethnic politics focus on attributes that make ethnic identity particularly salient, for example, physical traits that are difficult to change and noticeable. If the identities marked by these attributes are linked to social mobility, their noticeability and unchangeability make them highly salient. Since social mobility is an integral element of many accounts of separatism, such attributes are of clear relevance to determining if members of an ethnic group support separatism.

However, there is no prima facie reason to believe that all of these attributes must be "ethnic" in the sense of being descent-based. This claim is particularly true in the case of peripheral identity, where proximity may lead members of different groups to exhibit similar attributes through intermarriage or, as I argue, similar linguistic repertoires. ${ }^{2}$ As a result, attempts to measure

\footnotetext{
${ }^{1}$ Given ongoing debates about ethnic identity (Chandra 2006; Hale 2017), I use an expansive definition: ethnicity is a social identity defined by an idea of common descent; and members generally share a common culture or descent-based attributes.

${ }^{2}$ Linguistic repertoires are "the set of speech forms that a person commands" (Laitin 2000, 144).
} 
peripheral identity by identification with a demographically dominant ethnic group may miss the more important attributes that unite or divide residents of a peripheral region.

\section{Language and Separatism}

I argue that language is an attribute that: (1) has a clear link to ethnic theories of separatism; and (2) is conceptually and empirically distinct from ethnic identity, cutting across and within ethnic divides. The theoretical link between language and separatism is twofold. First, scholars have long noted the importance of language for developing a common national identity (Anderson 2006; Liu 2015; Wimmer 2018) or other politically salient identities among otherwise disparate communities (Laitin 1998). Second, an individual's linguistic repertoire is also difficult to change and noticeable (Marquardt 2018). As a result, linguistic fluency sends a strong signal of group membership-be it of the central or peripheral group. Even if language does not determine membership in high-prestige groups, it is still generally necessary for social mobility: knowledge of high-status languages can determine access to important institutions. For example, if an individual does not speak the language of business in a society, they will have difficulty finding highpaying employment. As a result, individuals have a strong incentive to reside in a region where their language is prestigious and supported by the state, regardless of its identity content.

For both of these reasons, an individual's linguistic repertoire has a clear link to regional sovereignty and thus separatism. If an individual faces discrimination because they do not speak the central language, or if they cannot find employment for the same reason, they have a strong incentive to support greater sovereignty in a region where their colinguals dominate. As a corollary, if proficiency in a peripheral language is essential for membership in a peripheral identity group, a nonspeaker of this language will have little incentive to support regional sovereignty. Indeed, if they speak the central language, they have strong reason to support greater integration with the center. ${ }^{3}$

Other work on language and separatism generally uses language to proxy strength of ethnic identification (Bormann, Cederman, and Vogt 2017; Hale 2008), positing that an individual who identifies with the language of their group (for example, considers it their "native" language) identifies to a greater extent with their group than a co-ethnic who does not. In contrast, I argue that the key aspect of language is proficiency, which facilitates membership in the identity groups to which a language is linked and allows access to resources that require linguistic knowledge.

The focus on identification with ethnic languages is thus potentially misleading. Unlike ethnic attributes, linguistic repertoires are not descent based. Parents have a strong incentive to teach their children the language of a central state or a regional lingua franca in order to ensure that they are able to communicate with other residents of their country or region, as well as access state services. If these languages are linked to membership in a high-status group, encouraging capabilities in these languages is of even greater importance (Laitin 1998). As a result, children often have a different linguistic repertoire than their parents and may not even develop competencies in their ethnic language, even if they identify with it. Linguistic fluency thus cuts across ethnic boundaries and creates linguistic identities-and thus preferences over separatist outcomes - distinct from their ethnic counterparts. Indeed, the language most salient for separatism may not even be ethnic, in the sense of being most closely linked to a regionally dominant ethnic group: if there is another peripheral language (for example, a lingua franca) that is more important to an individual's day-to-day life and social mobility in the peripheral region, this language will be more salient for separatist sentiment. ${ }^{4}$

\footnotetext{
${ }^{3}$ This argument runs parallel to Hale (2008). Unlike Hale, I argue that language-even in the absence of a common ethnic identity-can serve as a "rule of thumb" allowing individuals to determine sovereignty outcomes of most benefit to them.

${ }^{4}$ This discussion of social mobility does not discount the importance of language to peripheral identity, just that this identity is necessarily related to a specific peripheral ethnic identity. Along similar lines, I do not argue that the lingua francas that
} 


\section{Separatism in Pridnestrovie and Gagauzia}

I examine the link between language and separatism using two cases, both regions of the former Soviet republic of Moldova: Pridnestrovie and Gagauzia (see Figure 1). Both Pridnestrovie and Gagauzia had separated from the then Moldavian Soviet Socialist Republic (MSSR) by $1991 .{ }^{5}$ While Gagauzia reintegrated with the newly independent Moldova as an autonomous territorial unit in 1994, Pridnestrovie has remained de facto independent after a war with Moldova proper that ended in a 1992 ceasefire agreement. While separatism in both regions-in particular, Gagauzia-could plausibly have ethnic origins, linguistic dynamics provide a compelling alternative explanation. Moreover, historical circumstances in these regions have yielded a situation in which it is possible to disaggregate language from ethnic identity to a greater extent than is often possible, providing leverage for analyzing the effect of both ethnic identity and language on separatist sentiment.

\section{Ethnicity and Separatism in Pridnestrovie and Gagauzia}

Following from the highly ethnicized Soviet system (Brubaker 1994; Slezkine 1994), work on separatism and conflict in the former Soviet Union has emphasized the presence of a concentrated peripheral population in determining patterns of nationalist mobilization in the 1980s and 1990s (Hale 2000; Hale 2008; Toft 2005).

Given this context, Gagauzia appears to be a typical case for separatism: it is the homeland of the Turkic Gagauz people, and ethnic Gagauz represent the overwhelming majority of its population. In contrast, Moldova proper is largely ethnically Moldovan, and its nationalist movement had strong chauvinist tendencies during the disintegration of the Soviet Union. Moreover, the Gagauz have a history of grievances against Moldovans (Katchanovski 2005; Katchanovski 2006); work on horizontal inequalities would suggest that they are likely to engage in separatism since they are also a politically excluded group in a relatively poor region (Cederman, Gleditsch, and Buhaug 2013; Horowitz 2000).

Pridnestrovie is perhaps a less typical case of ethnic separatism. At the time of the region's declaration of independence, its population was roughly equally divided among ethnic Moldovans, Russians, and Ukrainians. In fact, ethnic Moldovans constituted a slight plurality of the region's population. Nevertheless, scholars link Pridnestrovian separatism to Russian identity, with Russians constituting approximately 30 per cent of Pridnestrovie's population in 1991. For example, Laitin (2001) argues that Pridnestrovian separatism is a case of a "triadic nexus" (Brubaker 1996): an external homeland (Russia) provided support for a minority population (Russians) in a nationalizing state (Moldova). Indeed, the role of Russia in Pridnestrovian separatism is undeniable: Russian military intervention cemented Pridnestrovie's de facto independence; and Russia's continued ties with the region are of utmost importance to its economic and political system. ${ }^{7}$ As a result, integration with Russia is perceived to be a plausible outcome

become main peripheral languages are identity neutral, just that salience of these identities for separatism is related to the language's relationship to regional sovereignty. For example, in the former Soviet Union, the Russian language is linked to the Soviet state, the Russian Federation, and ethnic Russians; it allows speakers to consume Russian-language media, travel and work in Russia, and communicate freely with other Russian speakers worldwide. These factors certainly influence the content of Russian-speaking identity. However, while there are many speakers of Russian worldwide, only in certain contexts is the language salient for separatism.

${ }^{5}$ Both regions had eventually declared themselves republics on a par with the MSSR and directly subordinate to the Soviet government. These-and subsequent-declarations were not recognized by the MSSR, the greater Soviet government, or any other widely recognized governing body.

${ }^{6}$ Scholarship on late-Soviet ethnic mobilization also argues that ethnofederal institutions facilitated ethnic and separatist mobilization (Beissinger 2002; Bunce 1999; Gorenburg 2003; Griffiths 2016; Hale 2008; Roeder 1991). Since neither Pridnestrovie nor Gagauzia possessed such ethnofederal institutions until they declared themselves separate from Moldova, they fit uneasily into these accounts.

${ }^{7}$ Liu, Roosevelt, and Sokhey (2017) illustrate that economic ties can increase a government's support for a lingua franca, specifically in the form of language laws. However, the degree to which economic ties increase popular support for specific 


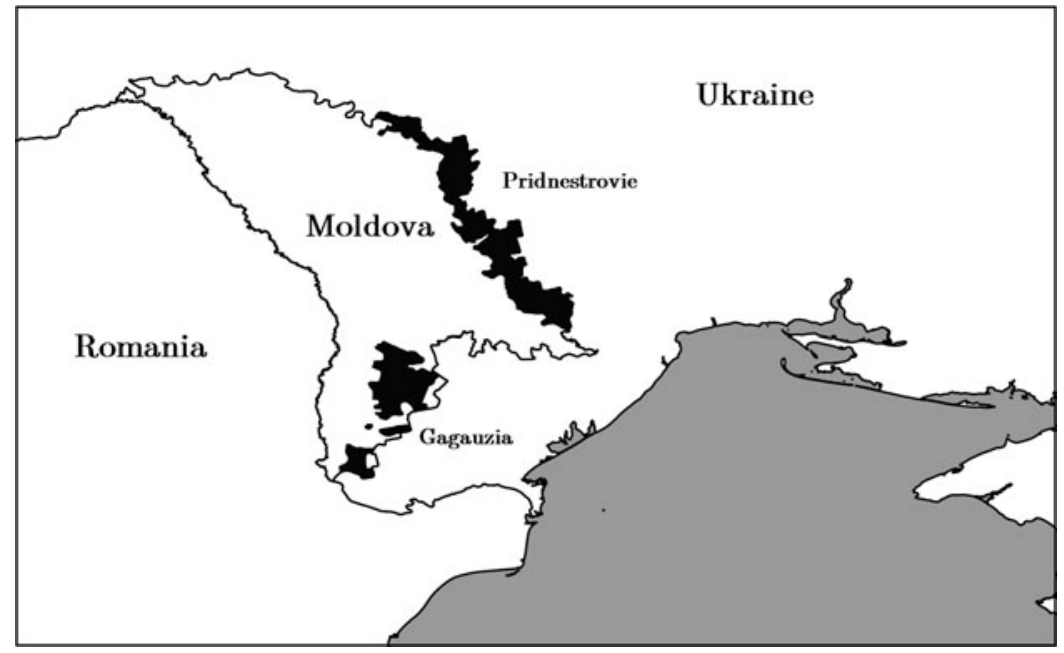

Fig. 1. Pridnestrovie and Gagauzia.

Note: Pridnestrovie and Gagauzia are shaded in black.

for Pridnestrovian separatism: when Pridnestrovie held a referendum on independence in 2006, 97 per cent of voters supported independence followed by integration with Russia (TsIK PMR no date).

\section{Language and Separatism in Pridnestrovie and Gagauzia}

Linguistic dynamics provide a compelling alternative explanation for separatism in Pridnestrovie and Gagauzia: Russian is the peripheral lingua franca in both regions, while Moldovan is the dominant language of the central state, Moldova. ${ }^{8}$ In this context, Russian speakers should support separatism, while Moldovan speakers should oppose this outcome.

Patterns of separatism in the 1990s indicate that this explanation is plausible. Moldovan nationalists in the late 1980s demanded a greater role for their language in Moldovan affairs, a stance that drew opposition from speakers of other languages, including much of the population of Pridnestrovie and Gagauzia (Crowther 1991). Indeed, the 1989 Moldovan Law on Languageswhich named Moldovan the sole state language of the Moldovan Soviet Socialist Republic and demoted Russian from its state language status to a "language of interethnic communication"-directly preceded both regions declaring themselves no longer subordinate to Moldova (King 1999; Skvortsova 2002).

The importance of the Russian language points to holes in ethnic explanations for separatism in Pridnestrovie and Gagauzia. There is strong evidence that separatism in Pridnestrovie was a multiethnic phenomenon, with support from both Moldovans and Ukrainians. Instead of ethnicity, the Russian language united the Pridnestrovian population in opposition to the Moldovan center (King 1999; Kolstø and Malgin 1998; Petersen 2012; Skvortsova 2002). In contrast, Moldovan was of limited use in the region, with education in the language only available in regions with compact settlements of ethnic Moldovans (Chinn and Roper 1995).

languages - and separatism - is unclear. Online Appendix L analyzes the relationship between time spent in Russia-a particularly prominent individual-level link to Russia that often has an economic cause-and support for different separatist outcomes. The analyses indicate that the relationship between spending time in Russia and support for separatist outcomes varies across both regions and outcomes.

${ }^{8}$ Moldovan is a Romance language that is mutually intelligible with Romanian, and whether or not they are the same language has been the subject of debate (Ciscel 2006). 
If language is important solely as a symbol of ethnic identity, then the Gagauz language should have played a role in Gagauz separatism similar to that which Russian played in Pridnestrovie. Indeed, the nationalist organization Gagauz Halk1, which stood at the forefront of Gagauzia's sovereignty movement, had agitated for raising the status of the language (Zabarah 2012). However, the Gagauz language did not play a prominent role in social mobility in Gagauzia until the midto late 1980s: up to this point, only Russian and Moldovan were taught in schools, and there was no Gagauz-only media. As a consequence, many Gagauz were more comfortable in Russian than Gagauz (Chinn and Roper 1998). Russian was thus the lingua franca in the region, and defending the Russian-not Gagauz-language garnered widespread support for Gagauz sovereignty (Chinn and Roper 1998; Zabarah 2012).

The importance of the Russian language in both regions has continued, even as the Moldovan language has assumed a greater role in Moldova proper. Russian-speaking Pridnestrovians have particularly strong incentives to support regional sovereignty since reintegration with Moldova could endanger the relatively privileged status of their language: Moldovan, Russian, and Ukrainian are state languages of Pridnestrovie, while neither Russian nor Ukrainian has such status in Moldova proper. Accordingly, data from a 2013 survey illustrate that a majority of Pridnestrovians believe that the Pridnestrovian government is more supportive of the Russian and Ukrainian languages than the Moldovan government, and that these languages are more frequently used in Pridnestrovie than Moldova proper; the opposite results hold for the Moldovan language. ${ }^{9}$ Evidence from focus groups demonstrates that these linguistic perceptions have political implications, with Russian speakers citing linguistic concerns when discussing reintegration with Moldova (Beyer 2011).

A similar situation has emerged in Gagauzia. Although Gagauzia's formative documents (for example, its constitution) call for raising the status of the Gagauz language, Russian (and Moldovan) has equal formal status in the region. As in Pridnestrovie, 2013 survey data indicate that a large majority of Gagauz respondents believe that the regional government supports the Russian and Gagauz languages more than the Moldovan government, and these languages are more frequently used in the region; they report the opposite vis-à-vis Moldovan. These data also indicate that Russian use remains as common as that of Gagauz, if not more so: 21 per cent of respondents consider Russian more widely used than Gagauz, compared to 12 per cent who believe the opposite. In line with their linguistic affinities, residents of Gagauzia have also shown notable pro-Russian tendencies. For example, in a 2014 regional referendum, Gagauzia residents supported Moldova entering the Russia-backed customs union and were against further integration with the European Union; they also backed contested regional legislation granting Gagauzia the right to secede should Moldova lose its status as an independent country (Regnum 2014).

\section{Empirical Analyses}

The preceding discussion yields clear implications for analyses of support for separatism in both regions. Ethnic theories of separatism hold that members of peripheral groups-Russians in Pridnestrovie and Gagauz in Gagauzia-should be the most supportive of separatism, while members of the dominant group of the central state-Moldovans-should be the least supportive of this outcome. In contrast, a theory of separatism that focuses on language would argue that speakers of Russian - the main peripheral language in both regions-should be the most supportive of separatism, while speakers of Moldovan - the language of the central state-should be the least supportive of this outcome.

This linguistic explanation also has implications for secondary languages in both territories: Gagauz in Gagauzia and Ukrainian in Pridnestrovie. Ethnic theories of conflict generally hold that

\footnotetext{
${ }^{9} \mathrm{I}$ describe this survey in greater detail in Online Appendix A and present more detailed analyses of how respondents perceive the salience of relevant languages in Online Appendix B.
} 
language is a symbol of ethnic identity (Horowitz 2000). The Gagauz language should thus be the most salient language for separatism in Gagauzia. In contrast, a linguistic theory would hold that the most salient language should be that which is most important for day-to-day life. As a result, Russian proficiency should be a stronger predictor of support for separatism than Gagauz.

In Pridnestrovie, Ukrainian proficiency is largely restricted to ethnic Ukrainians, who constitute less than a third of Pridnestrovie's population. Unlike Russian, it is not a peripheral lingua franca and is thus less relevant to social mobility in the region. However, the Ukrainian language is protected in the region and not in Moldova proper. Ukrainian speakers should therefore tend to support separatism, though to a lesser extent than Russian speakers.

To examine these empirical expectations, I conduct statistical analyses of original 2013 survey data from both Pridnestrovie and Gagauzia. The analyses proceed as follows. First, I discuss the data with a focus on the identification of linguistic effects. Second, I use observational data to analyze linguistic and ethnic correlates of support for separatism, finding that proficiency in the main peripheral language (Russian) is strongly correlated with support for separatism in both regions. Third, I provide experimental evidence that the relationship between language and support for separatism is, in fact, linguistic: linguistic primes increase the salience of linguistic-not ethnic-correlates of separatism.

\section{The Data}

The survey employed a computer-assisted personal interview strategy, and respondents had the opportunity to take the survey in any of the three official languages of their region. The Pridnestrovian sample includes 577 respondents (25 per cent response rate), while the Gagauz sample includes 836 (35 per cent response rate). ${ }^{10}$

\section{Ethnicity and Language in Pridnestrovie and Gagauzia}

Table 1 provides descriptive statistics regarding the relationship between language and ethnicity in both regions. As a measure of ethnic identity, I use a dichotomous indicator of the ethnic group to which a respondent reports primarily belonging. ${ }^{11}$ To measure whether or not an individual is fluent in a language, I dichotomize responses to a five-point Likert scale question that asks the respondent to report their level of spoken proficiency in Russian (the main peripheral language in both regions), Moldovan (the central language), and Ukrainian/Gagauz (secondary peripheral languages). I use the highest level_- "I am fluent"-as the indicator of fluency. Columns represent different ethnic groups, with "All" representing all respondents in a given region and the remaining columns presenting data from members of groups linked to regionally relevant languages. Rows represent the proportion of respondents of different groups who report speaking different languages fluently.

The data reveal that Russian functions as a lingua franca in both regions, with a majority of members of all ethnic groups reporting fluency in the language. Other languages-Moldovan and Ukrainian in Pridnestrovie, and Moldovan and Gagauz in Gagauzia-show a stronger connection to ethnic identity: it is generally members of these groups who report speaking their languages fluently. However, there is substantial variation within these groups in terms of fluency in their respective native tongues. This combination of widespread fluency in Russian and intraethnic variation in native language fluency allows for the disaggregation of language from ethnic identity in analyses of support for separatism.

\footnotetext{
${ }^{10}$ Response rates were calculated using the American Association for Public Opinion Research (AAPOR 2011) standard definitions minimum response rate formula RR1. For details on the survey methodology, see Online Appendix A.

${ }^{11}$ The legacy of Soviet-era institutionalization of ethnic identity in these regions means that respondents were readily able to provide a unique ethnic identity (natsional'nost').
} 
Table 1. Distribution of linguistic fluency across ethnic groups in Pridnestrovie and Gagauzia

\begin{tabular}{|c|c|c|c|c|}
\hline & & $\begin{array}{l}\text { Main peripheral } \\
\text { group }\end{array}$ & $\begin{array}{l}\text { Central } \\
\text { group }\end{array}$ & $\begin{array}{l}\text { Secondary peripheral } \\
\text { group }\end{array}$ \\
\hline & All & Russian & Moldovan & Ukrainian \\
\hline \multicolumn{5}{|l|}{ Pridnestrovie } \\
\hline Fluent in main peripheral language (Russian) & 0.93 & 1.00 & 0.86 & 0.89 \\
\hline Fluent in central language (Moldovan) & 0.21 & 0.03 & 0.77 & 0.08 \\
\hline $\begin{array}{l}\text { Fluent in other peripheral language } \\
\text { (Ukrainian) }\end{array}$ & 0.19 & 0.03 & 0.04 & 0.66 \\
\hline \multirow[t]{2}{*}{ N } & 577 & 278 & 132 & 146 \\
\hline & All & Gagauz & Moldovan & Russian \\
\hline \multicolumn{5}{|l|}{ Gagauzia } \\
\hline Fluent in main peripheral language (Russian) & 0.74 & 0.74 & 0.56 & 0.93 \\
\hline Fluent in central language (Moldovan) & 0.08 & 0.02 & 0.80 & 0.10 \\
\hline Fluent in peripheral ethnic language (Gagauz) & 0.74 & 0.89 & 0.15 & 0.17 \\
\hline N & 836 & 670 & 55 & 29 \\
\hline
\end{tabular}

\section{Identification and Measurement of Linguistic Fluency}

Although there is substantial intra- and interethnic variation in linguistic fluency in both Pridnestrovie and Gagauzia, identifying the effect of language remains a concern: a variety of factors-in particular, identity-could determine both the language(s) in which an individual is fluent and their preferences over separatist outcomes. I have engaged with these identification concerns in three main ways. First, I include the clearest potential confounding variable (ethnic identity) in all regression analyses of observational data. Second, I also analyze experimental data regarding the salience of language (versus ethnic identity) for support for separatism. Third, the Online Appendix contains detailed analyses of my operationalization of linguistic fluency, which I briefly sketch here.

A foremost identification concern is that respondents report fluency in a language based on their identification with groups with which the language is associated. Analyses in the Online Appendix indicate that this concern is at least not wholly warranted in this context. Online Appendix E examines the reasons respondents report learning languages, finding that individuals who learned a language for identity-based reasons are not more likely to report fluency in the language than those who report learning it for more utilitarian reasons. Online Appendix $\mathrm{C}$ explores the relationship between language and ethnic identity specifically. These analyses show that survey respondents are more likely to consider patrilineal descent as important for ethnic group membership than they are language, though language is also an important ethnic symbol in Gagauzia in particular.

Along similar lines, it is also possible that ties to Russia-in particular, spending an extended period of time in the country-could lead to increased proficiency in Russian and thereby stronger separatist sentiment. However, Online Appendix L presents analyses which indicate that there is little relationship between spending time in Russia and self-reported Russian fluency, which makes sense given the ample opportunities to develop fluency in the language in both Pridnestrovie and Gagauzia.

Moreover, Online Appendix D provides evidence that an adult's ability to develop fluency in a new language is likely constrained regardless of their identity. Specifically, survey data indicate that self-reported fluency in a language is rare among respondents who reported learning it as an adult. This result dovetails with psycholinguistic research on language acquisition, which holds that developing fluency in a new language is hard-if not impossible-for most adults (Abrahamsson and Hyltenstam 2009; Hyltenstam and Abrahamsson 2000).

I further validate this dichotomous indicator of linguistic fluency using a latent variable model (see Online Appendix N). The latent variable contains both self-reported fluency-the basis for 
the dichotomous indicators I use in the text-and responses to a variety of "can-do" questions (for example, "Can you talk about your day in language X?"). ${ }^{12}$ These analyses serve two purposes. First, analysis of the parameters of the latent variable model reveals that the fluency measure I use in the text provides a valid measurement of this concept: the level of self-reported proficiency is highly discriminatory across levels of the latent concept (speaking capabilities), indicating a strong relationship with the can-do indicators of proficiency. Second, I rerun the analyses of support for separatism using the latent variable estimates. The analyses indicate that the dichotomous indicator is a conservative way to analyze the relationship between language and separatism, with the continuous latent measurement showing consistently stronger results in theoretically expected directions. ${ }^{13}$

Finally, some of the effect of language on support for different separatist outcomes could be due to its relationship with media consumption. For example, Peisakhin and Rozenas (2018) illustrate that access to Russian-language media increases support for pro-Russian politicians in Ukraine. I analyze the relationship between language, media, and support for separatism in Online Appendix M. The analyses indicate that respondents generally do not watch media in a language in which they are not fluent and that many respondents gravitate toward Russian-language media. However, the relationship between language-of-media-consumption and separatism is distinct from that between linguistic fluency and separatism.

Despite this substantial evidence that self-reported linguistic fluency is measuring the intended concept, an important caveat to the following analyses remains. Language and sovereignty have an iterative relationship: sovereignty at time $t$ allows elites to increase the status of a peripheral language (Marquardt 2015), which, in turn, can reinforce peripheral sovereignty at time $t+1$ (Gorenburg 2003; Laitin 1988). Territorial linguistic endowments-and thereby sovereigntyalso influence an individual's linguistic calculations: it is rational for an individual to invest in teaching their child a language or trying to learn the language themselves only if others are doing the same (Laitin 1998). As a result, while these analyses provide insight into the relationship between language and separatism in these two regions in 2013, they are a snapshot of longer endogenous processes.

\section{Observational Analyses of Support for Separatism}

I use Bayesian ordinal probit regression analyses to observationally examine the relationship between linguistic fluency, ethnic identity, and support for separatism in both regions. Specifically, I regress individual-level support for regional independence-a quintessential separatist outcome-on linguistic and ethnic covariates, as well as standard demographic covariates. I use ordinal probit models due to the ordered-categorical outcome and a Bayesian approach for reasons detailed in the following section. While I do not pool the Pridnestrovie and Gagauzia data, the models are similar enough to discuss together.

\section{Data and Model}

I measure a respondent's support for regional independence using a five-point Likert scale, with responses ranging from "Fully disagree" to "Fully agree." ${ }^{\prime 4}$ I use the previously discussed dichot-

\footnotetext{
${ }^{12}$ For a discussion of the relative validity of such indicators, see Li and Zhang (2021).

${ }^{13}$ These results also indicate that the results are not just a function of the cutoff point on the scale that I use to assess linguistic fluency (Hu and Liu 2020).

${ }^{14}$ Online Appendix I provides additional details regarding modeling strategies, including estimation equations; it also contains results for analyses of additional separatist outcomes (i.e., different forms of integration with Moldova, Russia, and Ukraine), which I estimate in the same model. I conduct all statistical analyses using the R package runjags (Denwood 2016) which, in turn, employs the statistical program JAGS (Plummer 2012). I create graphics using ggplot2 (Wickham 2009).
} 
omous indicators of ethnic identity and linguistic fluency to operationalize these concepts. ${ }^{15} \mathrm{I}$ also control for demographic factors, including dichotomous indicators for respondent gender, higher education, and residents of urban settlements. I also control for respondent income and age (both log-transformed). ${ }^{16}$

The Bayesian approach allows me to iteratively impute missing outcome values across draws from the Markov chain Monte Carlo (MCMC) algorithm based on a respondent's covariate values. Imputed responses will thus align with those of otherwise similar individuals who provided responses, albeit with uncertainty. ${ }^{17}$

\section{Support for Separatism in Pridnestrovie}

Figure 2 reports the median posterior probability and 95 per cent credible region that a Pridnestrovian respondent supports Pridnestrovian independence given different combinations of linguistic repertoires and ethnic affiliations. ${ }^{18}$ Given the relationship between ethnicity and language, I report only plausible ethnic and linguistic combinations on the vertical axis. ${ }^{19}$ "Monolingual" represents an individual who is fluent in only one language, while "bilingual" represents an individual who is fluent in two languages.

I order the ethnic-linguistic combinations first by ethnic group and then by linguistic combination; a lower position in the figure corresponds to a higher expected probability of supporting separatism. Given theoretical expectations from the ethnic politics literature, the central ethnic group (Moldovans) should have the lowest probability of supporting separatism and the main peripheral group (Russians) the highest; secondary peripheral groups (for example, Ukrainians) have more ambiguous expectations. In contrast, a linguistic theory of separatism holds that the most substantial variation in support for this outcome should occur within ethnic groups, with speakers of the peripheral language (Russian) most supportive of separatism and speakers of the central language (Moldovan) the least.

Figure 2 provides strong evidence in favor of linguistic explanations for separatism: proficiency in the main peripheral language (Russian) has the strongest relationship with support for separatism of all ethnic and linguistic characteristics. I estimate the probability that a monolingual Moldovan speaker (that is, a nonspeaker of Russian) supports separatism to be 0.24 less (95 per cent credible region [0.00-0.46]) than a monolingual Russian-speaking co-ethnic. There is a similar difference between monolingual Ukrainian and Russian-speaking Ukrainians: 0.24 (0.04-0.43). However, the analysis presents little evidence for a link between speaking the central

\footnotetext{
${ }^{15}$ I model the modal ethnic groups (Russians in Pridnestrovie and Gagauz in Gagauzia) as reference levels, with a dichotomous indicator representing individuals not of the modal group (with Moldovans as the reference category for this category in both regions). I include additional indicators for Ukrainian and Other in Pridnestrovie; and for Bulgarian, Ukrainian, Russian, and Other in Gagauzia. With regard to the linguistic variables, I use fluent Russian speakers as the reference level in both analyses and include indicators for respondents who are not fluent in Russian, fluent in Moldovan, and fluent in Ukrainian or Gagauz (Ukrainian in Pridnestrovie and Gagauz in Gagauzia).

${ }^{16}$ Online Appendix G provides descriptive statistics.

${ }^{17}$ This imputation approach could lead to misleading results if respondents who did not respond have systematically different preferences than demographically similar respondents who did. However, analyses of nonresponse (see Online Appendix K) indicate that nonrespondents tend to have ethnic and linguistic demographics similar to those respondents who provided socially undesirable responses, i.e., opposition to independence in Pridnestrovie and autonomy in Gagauzia. If anything, the results therefore underestimate the magnitude of some linguistic and ethnic characteristics.

${ }^{18}$ Posterior probabilities are the estimated probability at each MCMC draw that an individual with given ethnic and linguistic characteristics would either "Fully agree" or "Agree" with a statement regarding a separatist outcome, holding all demographic controls constant at their modes or mean. This method takes measurement error in the form of uncertainty about both the coefficients and thresholds into account. Credible regions-here, highest posterior density intervals-are a Bayesian analog of confidence intervals.

${ }^{19}$ For example, since there are no Russians in the sample who are not fluent in Russian, it is untenable to make claims about monolingual Moldovan-speaking Russians.
} 


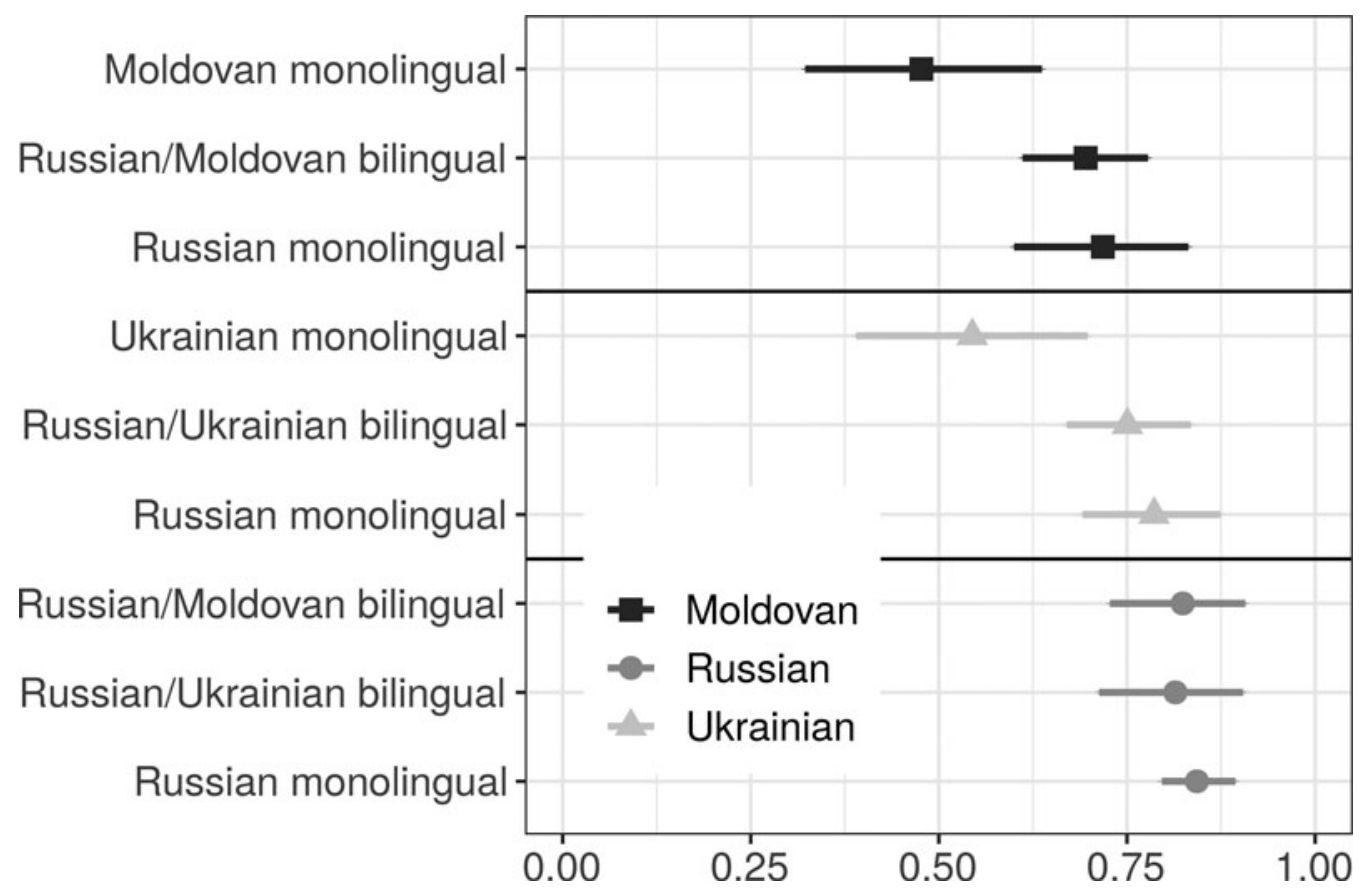

Fig. 2. Posterior probability that Pridnestrovian respondents support Pridnestrovian independence.

Notes: Points represent the posterior median and horizontal lines the 95 per cent credible regions over 500,000 iterations of four MCMC chains. Shading represents estimates for different ethnic groups; rows show linguistic repertoires.

language and support for separatism: bilingual Russian/Moldovan speakers tend to have similar political preferences as their monolingual Russian-speaking co-ethnics. ${ }^{20}$

In line with ethnic theories of separatism, there is evidence members of the central ethnic group are less supportive of separatism than those of the main peripheral group: a monolingual Russian-speaking ethnic Moldovan has a probability of supporting separatism that is 0.12 less $(0.00-0.26)$ than a linguistically equivalent Russian. However, the magnitude of the relationship between ethnicity and support for separatism is approximately half that of the relationship between proficiency in the peripheral language and support for separatism.

\section{Support for Separatism in Gagauzia}

Figure 3 presents results from the analysis of support for Gagauz independence. As with the Pridnestrovian results, I report the posterior probability that an individual with different ethnic identities and linguistic repertoires supports separatism. Ethnic Moldovans are the central ethnic group, and Moldovan is the central language, so monolingual Moldovan speakers are again at the top of the figure. Since Gagauz is the Gagauz ethnic language-and thus the most symbolically important peripheral language in line with ethnic theories of separatism-monolingual Gagauz speakers are placed at the bottom of the figure.

It should be noted that linguistic explanations of separatism would lead to a different ordering: Russian is the primary regional lingua franca in Gagauzia, as well as the language most closely

\footnotetext{
${ }^{20}$ In analyses that treat linguistic capabilities as a continuous variable, Moldovan proficiency shows a strong negative relationship with support for separatism; the relationship between Russian proficiency and support for separatism is magnified (see Online Appendix N).
} 


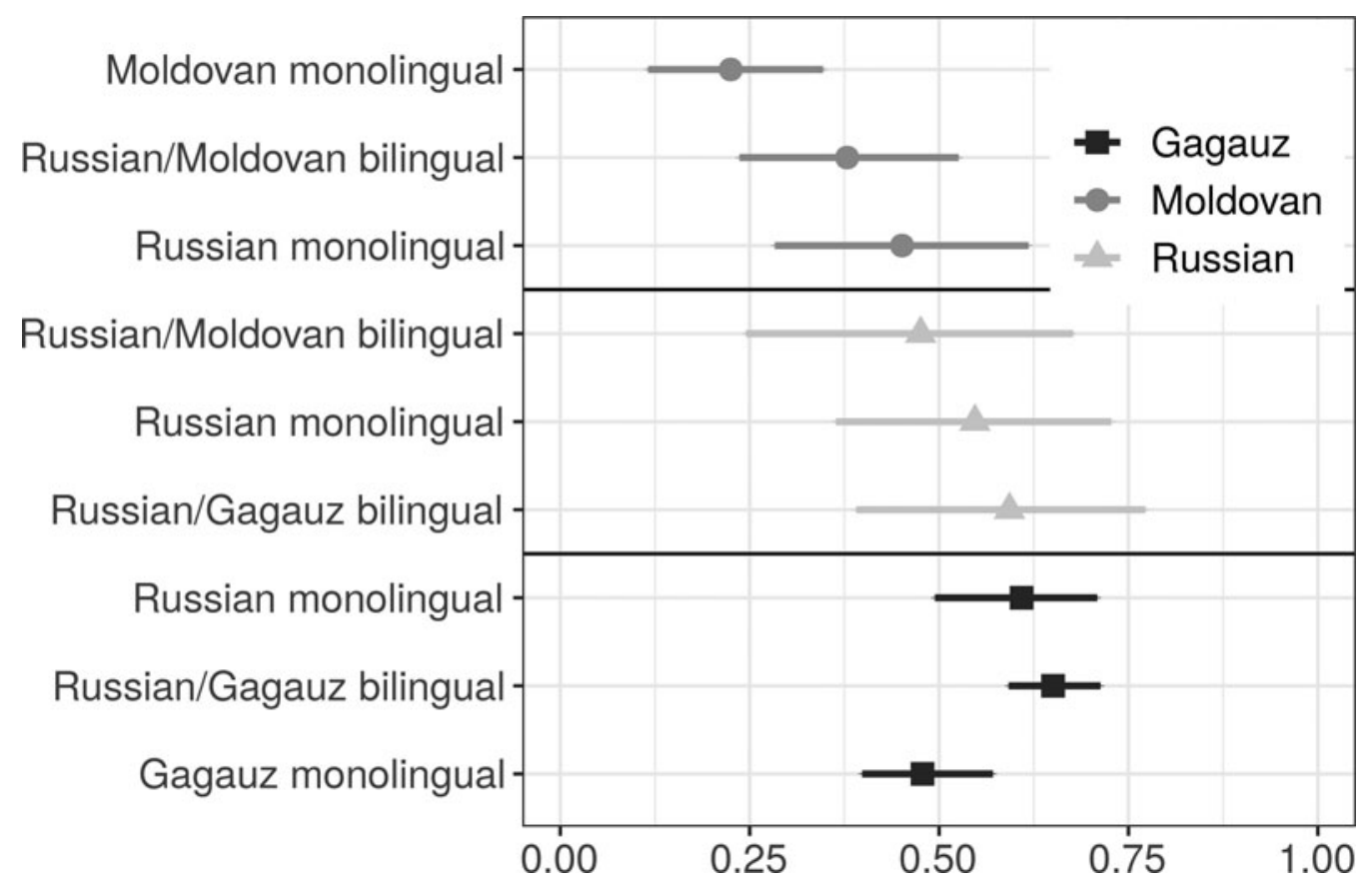

Fig. 3. Posterior probability that Gagauzia respondents support Gagauz independence.

Notes: Points represent the posterior median and horizontal lines the 95 per cent credible regions over 500,000 iterations of four MCMC chains. Shading represents estimates for different ethnic groups; rows show linguistic repertoires.

linked to status and social mobility. As in Pridnestrovie, Russian proficiency should therefore have the strongest correlation with support for separatism. ${ }^{21}$

The results are strongly in line with linguistic explanations of separatism: nonspeakers of the peripheral language (Russian) are the least supportive of this outcome. This result is starkest among monolingual Gagauz speakers. Contrary to the expectations of ethnic separatism, such a respondent has a posterior probability of supporting separatism that is 0.13 less than their monolingual Russian-speaking counterparts (95 per cent credible region [ -0.02 to 0.26$]$ ).

Results for ethnic Moldovans corroborate this argument. As in Pridnestrovie, there is evidence that ethnic identity is salient for support for separatism in Gagauzia: a monolingual Russian-speaking ethnic Moldovan is 0.16 less likely ( -0.00 to 0.33 ) to support separatism than their ethnic Gagauz linguistic counterpart. However, this difference is less than that between a monolingual Russian- and monolingual Moldovan-speaking ethnic Moldovan: a Moldovan speaker who does not speak the main peripheral language (Russian) has a probability of supporting separatism that is 0.22 less (0.06-0.38) than their monolingual Russian-speaking counterpart.

\section{Experimental Analyses}

Observational results provide strong evidence that linguistic abilities correlate with support for separatism in both Pridnestrovie and Gagauzia: respondents who lack fluency in the peripheral lingua franca are less likely to support separatism. However, they do not establish a causal link between linguistic proficiency and support for separatism. An ideal identification strategy

\footnotetext{
${ }^{21}$ Expectations for ethnic Russians are ambiguous, as they are a secondary peripheral group. I include posterior probabilities for members of this group to illustrate that Russian ethnic and linguistic effects are not the same.
} 
would involve randomly assigning linguistic proficiency to respondents. Since such an experiment is impossible for financial, ethical, and temporal reasons, I deploy priming experiments to determine whether linguistic cues increase the salience of ethnicity-the most likely confounding variable in this analysis-or linguistic capabilities.

The rationale for the experiments is that individuals may not explicitly consider their language or ethnic identity when determining preferences over separatist outcomes. Priming individuals to consider their linguistic abilities should make these abilities salient, intensifying their link to political preferences.

Linguistic explanations of separatism yield clear expectations for these analyses: linguistically primed individuals who either speak the central language (Moldovan) or do not speak the main peripheral language (Russian) should be less supportive of separatism than individuals who are not primed to consider the relevant languages. On the other hand, if the importance of language lies in its symbolic relationship with ethnicity, then the primes should intensify the relationship between ethnic identity and support for separatism, for example, linguistically primed ethnic Moldovans should be less supportive of separatism, regardless of their linguistic repertoire.

\section{Experimental Design}

For the experiment, survey software randomly assigned respondents to one of four conditions: a control, in which the respondent was presented with no linguistic prime; or one of three linguistic primes related to Moldovan, Russian, or Ukrainian/Gagauz fluency (Ukrainian in Pridnestrovie; Gagauz in Gagauzia). The primes involve asking the respondent "Do you speak X fluently?" with $\mathrm{X}$ corresponding to one of the aforementioned languages. ${ }^{22} \mathrm{I}$ henceforth refer to these treatments

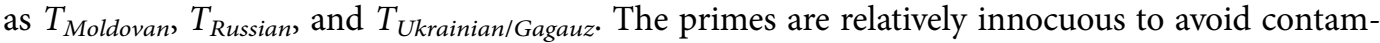
ination of the results by introducing additional content into the question: the results would likely be more pronounced had the prime packed more political or cultural punch (Pérez 2015). Following the prime, enumerators asked respondents their preferred outcome for regionMoldova political relations, with the options of their region becoming: (1) part of Moldova without autonomy; (2) part of Moldova with autonomy; (3) part of a confederation with Moldova; or (4) a separate state.

\section{Bayesian Hierarchical Analyses}

I use Bayesian hierarchical models to analyze the experimental data because theory yields a strong a priori assumption of heterogenous treatment effects: the primes should intensify either linguistic or ethnic preferences with regard to separatism, leading individuals with different linguistic and ethnic backgrounds to respond differently to them. ${ }^{23}$ Moreover, there are multiple potential interactions between the treatments and linguistic and ethnic variables. For example, $T_{\text {Russian }}$ could remind monolingual Moldovan speakers of the Russian language's privileged status in Pridnestrovie, reducing their support for separatism. Explicit modeling of these interactionsand reporting these results-is therefore necessary (Imai and Ratkovic 2013). The Bayesian hierarchical modeling approach I use here reduces the risk of false positives by shrinking the conditional effect of each covariate based on an underlying distribution (Feller and Gelman 2014).

\section{The Model}

I use an ordinal probit model to assess the relationship between language, ethnicity, and support for separatism. The highest level of the outcome represents support for separate statehood; the lowest level represents support for full integration with Moldova. I hierarchically cluster

\footnotetext{
${ }^{22}$ While experimental analyses in the area of language politics often involve manipulating the accent, register, or language to which subjects are exposed (Flores and Coppock 2018; Hopkins 2014; Ricks 2020), my priming treatment more closely hews to the experimental identity politics literature, in which subjects are asked to consider their membership in different relevant groups (Transue 2007).

${ }^{23}$ Online Appendix J provides $t$-test results, as well as a more analytic description of the model.
} 
experimental condition intercepts and coefficients for the three linguistic covariates (Not fluent in Russian, Fluent in Moldovan, and Fluent in Ukrainian/Gagauz) and ethnic covariates. Since there is no theoretical reason to believe that the relationship between the demographic controls and support for separatism varies across treatments, I model their coefficients as treatment invariant.

\section{Pridnestrovie Experimental Results}

Figure 4 presents results from the Pridnestrovie priming experiment. It reports the posterior probability that respondents with different ethnic and linguistic characteristics would support Pridnestrovian independence, across experimental outcomes. The cells are divided first by the respondent's linguistic repertoire, then by experimental condition; the bottom row of each ethnic-linguistic repertoire represents an individual in the control condition. I focus on ethnic Russians and Moldovans since these groups contain the ethnic and linguistic combinations with the clearest empirical expectations. ${ }^{24}$ Specifically, if the salience of language lies in its relationship to linguistic capabilities - as opposed to ethnic identity- $T_{\text {Moldovan }}$ should decrease support for separatism among Moldovan speakers, while $T_{\text {Russian }}$ should increase support for separatism among Russian speakers. On the other hand, if language is primarily important as a symbol of ethnic identity, then $T_{\text {Moldovan }}$ should decrease support for separatism among ethnic Moldovans, while $T_{\text {Russian }}$ should increase support for separatism among ethnic Russians, regardless of their linguistic repertoires.

The clearest experimental result regards $T_{\text {Moldovan }}$, which consistently decreases the posterior probability that a speaker of the central language (Moldovan) would support separatism, in line with linguistic explanations for separatism. For example, the median posterior difference in the probability that an ethnic Moldovan (bottom cell) who is bilingual in Russian and Moldovan would support Pridnestrovian independence in the $T_{\text {Moldovan }}$ versus control condition is -0.30 (95 per cent credible region [ -0.52 to -0.05$]$ ); for a monolingual Moldovan speaker, the difference is -0.26 , albeit with high uncertainty due to the small sample size of monolingual Moldovan speakers. Similar priming effects are visible across ethnic groups: a bilingual Russian/Moldovan speaking Russian (top cell) is estimated to be 0.36 less likely ( -0.01 to 0.69 ) to support separatism in $T_{\text {Moldovan }}$ versus the control condition.

The fact that Moldovan proficiency shows a weaker relationship with support for separatism in the observational analyses is perhaps evidence that the Moldovan language is less salient to Pridnestrovians than the Russian language. While abilities (or lack thereof) in the main peripheral language is a constant factor in everyday life, the political importance of Moldovan proficiency may only be clear when respondents are thus reminded. This interpretation dovetails with the lack of evidence of a linguistic treatment effect for the peripheral language prime $\left(T_{\text {Russian }}\right)$ : since Russian is already salient, the prime is redundant.

The other important finding from the experiment is the null results for ethnic treatment effects. If linguistic primes were priming ethnic identity, then $T_{\text {Moldovan }}$ should reduce the posterior probability that all Moldovans support separatism. Instead, it only affects Moldovan speakers: if anything, this treatment increases the probability that monolingual Russian-speaking Moldovans support independence. Similarly, $T_{\text {Russian }}$ has little apparent effect on ethnic Russians (the main peripheral group), regardless of their linguistic repertoire.

\section{Gagauzia Experimental Results}

Figure 5 shows results from the survey experiment in Gagauzia, focusing on results for ethnic Gagauz with different linguistic repertoires (for results for other ethnic groups, see Online Appendix J). Given the small number of Gagauz who are fluent in Moldovan in the survey,

\footnotetext{
${ }^{24}$ Online Appendix J contains results for ethnic Ukrainians, as well as results for $T_{U k r a i n i a n}$, about both of which empirical expectations are less clear than for other ethnic groups and treatment conditions.
} 
Russian monolingual

Russian/Moldovan bilingual
Russian/Ukrainian bilingual

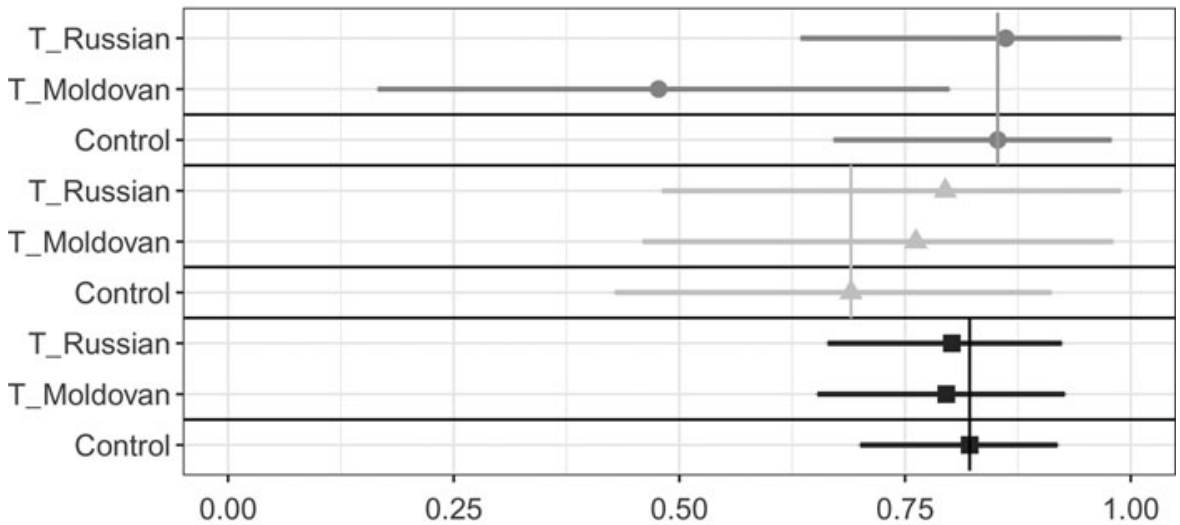

(a) Ethnic Russian

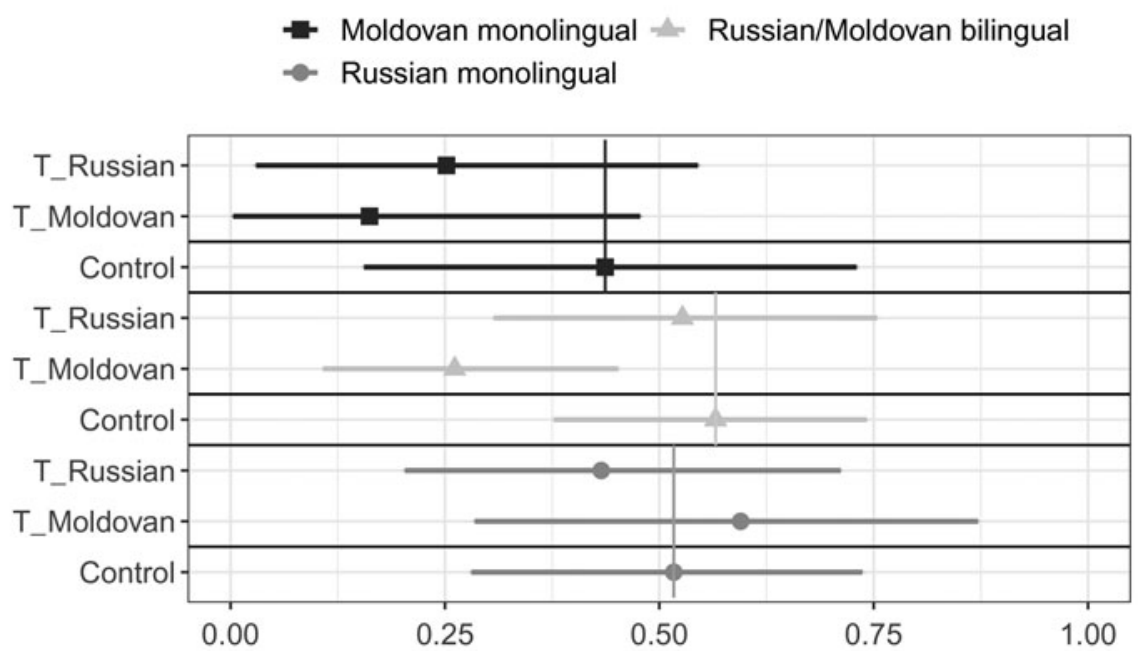

(b) Ethnic Moldovan

Fig. 4. Posterior probability of supporting Pridnestrovian independence across experimental conditions by ethnic group. Notes: Points represent the posterior median and horizontal lines the 95 per cent credible regions over 500,000 iterations of four MCMC chains. Shading represents estimates for different linguistic repertoires; rows show experimental conditions. Vertical lines represent the posterior median for an individual of a given linguistic repertoire in the control condition.

these results can only speak to the degree to which primes affect the relationship between separatism and different peripheral languages: Russian, the peripheral lingua franca, and Gagauz, the language most closely linked to peripheral ethnic identity. As with Pridnestrovie, the expectation is that $T_{\text {Russian }}$ intensifies support for separatism among Russian speakers. Expectations for Gagauz are ambiguous. Since the Gagauz language is closely linked to Gagauz sovereignty, $T_{\text {Gagauz }}$ should increase Gagauz speakers' support for separatism. However, as in the observational results, the Russian language's primary role in Gagauzia may mitigate this relationship. 
Gagauz monolingual Russian/Gagauz bilingual

\section{Russian monolingual}

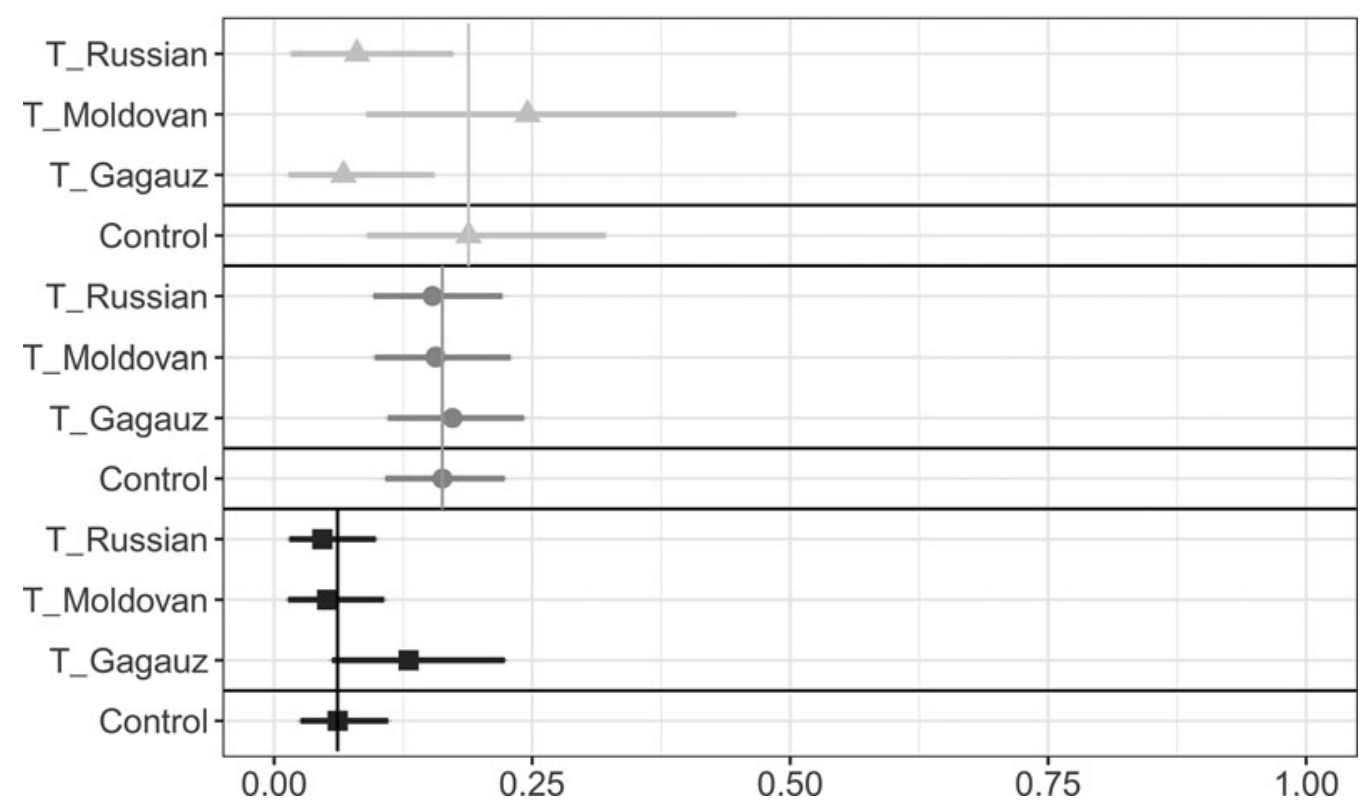

Fig. 5. Posterior probability that ethnic Gagauz support regional independence across experimental conditions. Notes: Points represent the posterior median and horizontal lines the 95 per cent credible regions over 500,000 iterations of four MCMC chains. Shading represents estimates for different linguistic repertoires; rows show experimental conditions. Vertical lines represent the posterior median for an individual of a given linguistic repertoire in the control condition.

The results indicate that the interplay between Gagauz fluency and support for separatism is more complicated than the observational results suggest. Most prominently, there is evidence that $T_{\text {Gagauz }}$ increases support for separatism among monolingual Gagauz speakers: the median posterior difference in the probability that a monolingual Gagauz speaker supports Gagauz independence between the control and $T_{\text {Gagauz }}$ conditions is 0.07 (95 per cent credible region $[-0.02$ to 0.17$]){ }^{25}$ While the credible region overlaps 0 , this result provides some evidence that increasing the salience of the language can increase the probability that its speakers support separatism. Indeed, the posterior probability that a monolingual Gagauz speaker supports separatism in $T_{\text {Gagauz }}$ is similar to the probability that a bilingual Gagauz/Russian speaker or monolingual Russian speaker supports separatism in the control condition $(0.13,0.16$, and 0.19 , respectively-all estimates well within uncertainty intervals).

Nevertheless, the effect of $T_{\text {Gagauz }}$ is not consistent among ethnic Gagauz with different linguistic repertoires. This result indicates that the priming effect is linguistic, not ethnic (that is, the prime increases the salience of the Gagauz language, not ethnic identity). The prime has no clear effect on the posterior probability that a bilingual Russian/Gagauz speaker would support separatism and actually has a negative effect on support for separatism among monolingual Russian-speaking Gagauz (a difference of -0.12 [ -0.26 to 0.01$]$ relative to the control condition).

Contrary to theoretical expectations, $T_{\text {Russian }}$ does not increase support for separatism among Russian speakers. It has no clear effect on support for separatism among bilingual Russian/

\footnotetext{
${ }^{25}$ Nonresponse analyses in Online Appendix $\mathrm{K}$ indicates that monolingual Gagauz speakers are particularly likely to respond in this treatment condition.
} 
Gagauz speakers and, if anything, a negative effect on monolingual Russian-speaking Gagauz $(-0.10[-0.25$ to 0.03$]$ relative to the control condition).

As a final comment, it should be noted that the support of bilingual Gagauz/Russian speakers for separatism is consistently strong across experimental conditions. ${ }^{26}$ In conjunction with (1) the evidence that individuals with this repertoire tend to be the most supportive of separatism relative to their monolingual Russian and Gagauz peers, (2) the counterintuitive experimental effects of $T_{\text {Gagauz }}$ and $T_{\text {Russian }}$ on monolingual Russian speakers, and (3) the positive effect of $T_{\text {Gagauz }}$ on support for separatism among monolingual Gagauz speakers, this result is perhaps evidence that both languages have an important role in support for Gagauz sovereignty, though their exact role remains contentious.

\section{Conclusion}

Language can provide a strong explanation for separatist sentiment, even in the absence of a link to ethnic identity. Speakers of a peripheral language have a strong incentive to support regional sovereignty, as doing so preserves the status of their language and thus their social mobility. In contrast, speakers of the language of the central state have an incentive to oppose separatism, as they will accrue greater benefits from integration with the state where their language enjoys a high status. Language can also cut across ethnic divides, unifying a multiethnic peripheral population in support of separatism. This argument runs counter to ethnic theories of separatism, which hold that ethnic identity determines an individual's support for separatism and that language is merely a proxy for ethnicity.

Results from observational analyses of Pridnestrovie and Gagauzia provide strong evidence supporting the linguistic argument. In both regions, individuals fluent in a peripheral lingua franca, Russian, are more supportive of separatist outcomes than individuals who are not fluent. This result holds across ethnic groups. Moreover, results from Gagauzia indicate that the effect of language is due not necessarily to its connection with ethnic identity, but rather to its role in social mobility and day-to-day life: monolingual speakers of a peripheral ethnic language (Gagauz) are less supportive of separatism than bilingual Gagauz/Russian speakers and monolingual Russian speakers with similar ethnic backgrounds.

Experimental results provide further evidence that the role of language in determining support for separatism is a function of linguistic proficiency, not ethnic identity. In Pridnestrovie, priming individuals to consider their proficiency in the Moldovan language decreases support for separatism among Moldovan speakers, regardless of their ethnic identification. In Gagauzia, priming for Gagauz proficiency increases support for separatism among monolingual Gagauz speakers, while decreasing support for separatism among monolingual Russian speakers. Given the prevalence of Russian in Gagauzia, this finding indicates that respondents require priming to make the Gagauz language salient for separatism. In all cases, there is little evidence in either region that the linguistic primes affect the relationship between ethnic identity and support for separatism.

These results have important implications for the study of identity and separatism. First, the consistent presence of linguistic appeals in separatist conflicts worldwide indicates that the linguistic dynamics at play in Gagauzia and Pridnestrovie may be of vital importance to understanding separatism elsewhere. Scholars should therefore not assume that language is a proxy for ethnic identity in cases of separatism and conflict, but consider linguistic differences themselves as having an important relationship with separatism. Second, in line with Liu (2015), scholars should consider the political relevance of language in their analyses. Politically relevant languages may

\footnotetext{
${ }^{26}$ Analyses of experimental data that use a continuous measure of linguistic proficiency indicate that $T_{\text {Gagauz }}$ increases support for separatism among both monolingual and bilingual Gagauz speakers, while reducing support for separatism among monolingual Russian speakers (see Online Appendix N).
} 
not be those of an ethnic group; a language's political relevance may instead come from its importance to everyday life and social mobility in both the periphery and the central state. Third, this article focuses on the political importance of linguistic fluency, which has a clear theoretical link to preferences over separatist outcomes. However, as Onuch and Hale (2018) note, different aspects of language have different implications for political preferences. Future research would do well to both theoretically and empirically probe how different aspects of language-for example, not only identification, but also levels and forms of proficiency, as well as accents-can influence preferences over separatism and other political outcomes of interest.

Supplementary Material. Online appendices are available at: https://doi.org/10.1017/S0007123421000533.

Data Availability Statement. Replication data files are available in Harvard Dataverse at: https://doi.org/10.7910/DVN/ TOJZPZ

Acknowledgments. I thank Yoshiko Herrera, Scott Gehlbach, Alexander Tahk, Rikhil Bhavnani, and Ted Gerber for their essential contributions to this project. I also thank Kristen Kao, John Ahlquist, Dominique Arel, Nicholas Barnes, Ruth Carlitz, Hannah Chapman, Matthew Ciscel, Barry Driscoll, Evgeny Finkel, Adam Harris, Bradley Jones, Patrick Kearney, David Laitin, Staffan Lindberg, Anna Lührmann, Ellen Lust, Israel Marques II, Juraj Medzihorsky, Rick Morgan, Marc Ratkovic, and Steven Wilson for their insights at different stages of this project. The survey benefited greatly from consultations with the staff of IMAS-Inc in Chisinau, especially Doru Petruți, Veronica Ateş, Elena Petruți, and Cristina Tudosov. Earlier drafts were presented at the 2015 Association for the Study of Nationalities World Convention and the 2016 UWMadison Comparative Politics Colloquium, as well as in seminars at the University of Gothenburg and the 2019 New Voices on Russia Seminar Series at George Washington University.

Financial Support. I acknowledge research support from: the National Science Foundation, Doctoral Dissertation Improvement Award No. 1160375; the Fulbright-Hays Doctoral Dissertation Research Abroad Fellowship; Riksbankens Jubileumsfond, Grant M13-0559:1; the Knut and Alice Wallenberg Foundation, Grant 2013.0166; the Swedish Research Council, Grant 439-2014-38; and the HSE University Basic Research Program. Statistical analyses used computational resources provided by the High Performance Computing section and the Swedish National Infrastructure for Computing (SNIC) at the National Supercomputer Centre in Sweden, SNIC 2017/1-406.

Competing Interests. None.

Ethical Standards. I conducted research according to protocols 2012-1016 and SE-2011-0189 of the University of Wisconsin-Madison Education and Social/Behavioral Science Institutional Review Board.

\section{References}

AAPOR (American Association for Public Opinion Research) (2011) Standard Definitions: Final Dispositions of Case Codes and Outcome Rates for Surveys, 7th edn. AAPOR.

Abrahamsson N and Hyltenstam K (2009) Age of onset and nativelikeness in a second language: listener perception versus linguistic scrutiny. Language Learning 59(2), 249-306.

Anderson B (2006) Imagined Communities, 2nd edn. New York, NY: Verso.

Beissinger MR (2002) Nationalist Mobilization and the Collapse of the Soviet State. New York, NY: Cambridge University Press.

Beyer J (2011) Routes across the Nistru. London: Saferworld.

Bormann N-C, Cederman L-E, and Vogt M (2017) Language, religion, and ethnic civil War. Journal of Conflict Resolution 61(4), 744-771.

Brubaker R (1994) Nationhood and the national question in the Soviet Union and post-Soviet Eurasia: an institutionalist account. Theory and Society 23(1), 47-78.

Brubaker R (1996) Nationalism Reframed: Nationhood and the National Question in the New Europe. New York, NY: Cambridge University Press.

Bunce V (1999) Subversive Institutions: The Design and Destruction of Socialism and the State. New York, NY: Cambridge University Press.

Caselli F and Coleman WJ (2013) On the theory of ethnic conflict. Journal of the European Economic Association 11(s1), 161-192.

Cederman L-E, Gleditsch KS, and Buhaug H (2013) Inequality, Grievances, and Civil War. New York, NY: Cambridge University Press. 
Cederman L-E, Wimmer A, and Min B (2010) Why do ethnic groups rebel? New data and analysis. World Politics 62(1), 87-119.

Chandra K (2006) What is ethnic identity and does it matter? Annual Review of Political Science 9, 397-424.

Chandra K (2012) Constructivist Theories of Ethnic Politics. New York, NY: Oxford University Press.

Chinn J and Roper SD (1995) Ethnic mobilization and reactive nationalism: the case of Moldova. Nationalities Papers 23(2), 291-325.

Chinn J and Roper SD (1998) Territorial autonomy in Gagauzia. Nationalities Papers 26(1), 87-101.

Ciscel MH (2006) A separate Moldovan language? The sociolinguistics of Moldova's limba de stat. Nationalities Papers 34(5), 575-597.

Crowther W (1991) The politics of ethno-national mobilization: nationalism and reform in Soviet Moldavia. The Russian Review 50(2), 183-202.

Denwood MJ (2016) runjags: an R package providing interface utilities, model templates, parallel computing methods and additional distributions for MCMC models in JAGS. Journal of Statistical Software 71(9), 1-25.

Esteban J, Mayoral L, and Ray D (2012) Ethnicity and conflict: an empirical study. The American Economic Review 102(4), $1310-1342$.

Feller A and Gelman A (2014) Hierarchical models for causal effects. In Scott RA and Kosslyn SM (eds), Emerging Trends in the Social and Behavioral Sciences: An Interdisciplinary, Searchable, and Linkable Resource. Thousand Oaks, CA: Sage.

Flores A and Coppock A (2018) Do bilinguals respond more favorably to candidate advertisements in English or Spanish? Political Communication 35, 612-633.

Gellner E (1983) Nations and Nationalism. Ithaca, NY: Cornell University Press.

Gorenburg DP (2003) Minority Ethnic Mobilization in the Russian Federation. New York, NY: Cambridge University Press.

Griffiths RD (2016) Age of Secession: The International and Domestic Determinants of State Birth. New York, NY: Cambridge University Press.

Gurr TR (1993) Minorities at Risk: A Global View of Ethnopolitical Conflicts. Washington, DC: United States Institute of Peace Press.

Hale HE (2000) The parade of sovereignties: testing theories of secession in the Soviet setting. British Journal of Political Science 30(1), 31-56.

Hale HE (2008) The Foundations of Ethnic Politics: Separatism of States and Nations in Eurasia and the World. New York, NY: Cambridge University Press.

Hale HE (2017) Focus on the fundamentals: reflections on the state of ethnic conflict studies. Ethnopolitics 16(1), 41-47.

Hopkins DJ (2014) The upside of accents: language, inter-group difference, and attitudes toward immigration. British Journal of Political Science 45, 531-557.

Horowitz DL (2000) Ethnic Groups in Conflict, 2nd edn. Berkeley, CA: University of California Press.

Hu Y and Liu AH (2020) The effects of foreign language proficiency on public attitudes: evidence from the Chinese-speaking world. Journal of East Asian Studies 20, 1-23.

Hyltenstam K and Abrahamsson N (2000) Who can become native-like in a second language? All, some, or none? On the maturational constraints controversy in second-language acquisition. Studia Linguistica 54(2), 150-166.

Imai K and Ratkovic M (2013) Estimating treatment effect heterogeneity in randomized program evaluation. The Annals of Applied Statistics 7(1), 443-470.

Katchanovski I (2005) Small nations but great differences: political orientations and cultures of the Crimean Tatars and the Gagauz. Europe-Asia Studies 57(6), 877-894.

Katchanovski I (2006) Cleft Countries: Regional Political Divisions and Cultures in Post-Soviet Ukraine and Moldova. Stuttgart: ibidem-Verlag.

King C (1999) The Moldovans: Romania, Russia, and the Politics of Culture. Stanford: Hoover Institution Press.

Kolstø P and Malgin A (1998) The Transnistrian republic: a case of politicized regionalism. Nationalities Papers 26(1), $103-127$.

Laitin DD (1988) Language games. Comparative Politics 20(3), 289-302.

Laitin DD (1998) Identity in Formation: The Russian-Speaking Populations in the Near Abroad. Ithaca, NY: Cornell University Press.

Laitin DD (2000) What is a language community? American Journal of Political Science 44(1), 142-155.

Laitin DD (2001) Secessionist rebellion in the former Soviet Union. Comparative Political Studies 34(8), 839-861.

Laitin DD and Ramachandran R (2016) Language policy and human development. American Political Science Review 110(3), 457-480.

Li M and Zhang X (2021) A meta-analysis of self-assessment and language performance in language testing and assessment. Language Testing 38(2), 189-218.

Liu AH (2015) Standardizing Diversity: The Political Economy of Language Regimes. Philadelphia, PA: University of Pennsylvania Press.

Liu AH, Roosevelt M, and Sokhey S (2017) Trade and recognition of commercial lingua francas: Russian language laws in post-Soviet countries. Economics \& Politics 29(1), 48-68. 
Marquardt KL (2015) Language and sovereignty: a comparative analysis of language policy in Tatarstan and Kazakhstan, 1991-2010. In Ayoob M and Ismayilov M (eds), Identity and Politics in Central Asia and the Caucasus. New York, NY: Routledge, pp. 44-68.

Marquardt KL (2018) Identity, social mobility, and ethnic mobilization: language and the disintegration of the Soviet Union. Comparative Political Studies 51(7), 831-867.

Marquardt KL (2021) Replication Data for: Language, Ethnicity and Separatism. https://doi.org/10.7910/DVN/TOJZPZ, Harvard Dataverse, V1.

Onuch $\mathrm{O}$ and Hale HE (2018) Capturing ethnicity: the case of Ukraine. Post-Soviet Affairs 34(2-3), 84-106.

Peisakhin L and Rozenas A (2018) Electoral effects of biased media: Russian television in Ukraine. American Journal of Political Science 62(3), 535-550.

Pérez EO (2015) Xenophobic rhetoric and its political effects on immigrants and co-ethnics. American Journal of Political Science 59, 549-564.

Pérez EO and Tavits M (2019) Language heightens the political salience of ethnic divisions. Journal of Experimental Political Science 6(2), 131-140.

Petersen R (2012) Identity, rationality, and emotion in the processes of state disintegration and reconstruction. In Chandra $\mathrm{K}$ (ed.), Constructivist Theories of Ethnic Politics. New York, NY: Oxford University Press, pp. 387-421.

Plummer M (2012) rjags: Bayesian graphical models using MCMC. https:/CRAN.R-project.org/package=rjags

Pop-Eleches G and Robertson GB (2018) Identity and political preferences in Ukraine-before and after the Euromaidan. Post-Soviet Affairs 34(2-3), 107-118.

Regnum (2014) Itogi referenduma v Gagauzii: 98.09 per cent—za nezavisimost, 98,47 per cent-za TS, 97,22 per cent-protiv ES. Available from https://regnum.ru/news/polit/1762107.html

Ricks JI (2020) The effect of language on political appeal: results from a survey experiment in Thailand. Political Behavior $\mathbf{4 2}$, 83-104.

Rodon T and Guinjoan M (2018) When the context matters: identity, secession and the spatial dimension in Catalonia. Political Geography 63, 75-87.

Roeder PG (1991) Soviet federalism and ethnic mobilization. World Politics 43(2), 196-232.

Siroky DS et al. (2021) Containing nationalism: culture, economics and indirect rule in Corsica. Comparative Political Studies 54(6), 1023-1057.

Skvortsova A (2002) The cultural and social makeup of Moldova: a bipolar or dispersed society? In Kolstø P (ed.), National Integration and Violent Conflict in Post-Soviet Societies: The Cases of Estonia and Moldova. Lanham, MD: Rowman \& Littlefield, pp. 159-196.

Slezkine Y (1994) The U.S.S.R. as a communal apartment, or how a socialist state promoted ethnic particularism. Slavic Review 53(2), 415-452.

Toft MD (2005) The Geography of Ethnic Violence: Identity, Interests, and the Indivisibility of Territory. Princeton, NJ: Princeton University Press.

Transue JE (2007) Identity salience, identity acceptance, and racial policy attitudes: American national identity as a uniting force. American Journal of Political Science 51, 78-91.

TsIK PMR (Tsentral'naia izbiratel'naia komissiia Pridnestrovskoi Moldavskoi Respubliki) (no date) Rezul'taty referenduma o nezavisimosti Pridnestrovskoi Moldavskoi Respubliki 17 sentiabria 2006 goda. Available from https://www.cikpmr.com/ o-vyborakh-i-referendumakh/informatsiya-referendumakh/rezultaty-referenduma-o-nezavisimosti-pridnestrovskoj-moldavskoj-respubliki-17-sentyabrya-2006-goda.html

Vogt M (2018) Ethnic stratification and the equilibrium of inequality: ethnic conflict in postcolonial states. International Organization 72, 105-137.

Wickham H (2009) ggplot2: Elegant Graphics for Data Analysis. New York, NY: Springer.

Wimmer A (2018) Nation Building: Why Some Countries Come Together While Others Fall Apart. Princeton, NJ: Princeton University Press.

Zabarah DA (2012) Opportunity structures and group building processes: an institutional analysis of the secession processes in Pridnestrovie and Gagauzia between 1989 and 1991. Communist and Post-Communist Studies 45(1), 183-192.

Cite this article: Marquardt KL (2022). Language, Ethnicity, and Separatism: Survey Results from Two Post-Soviet Regions. British Journal of Political Science 52, 1831-1851. https://doi.org/10.1017/S0007123421000533 